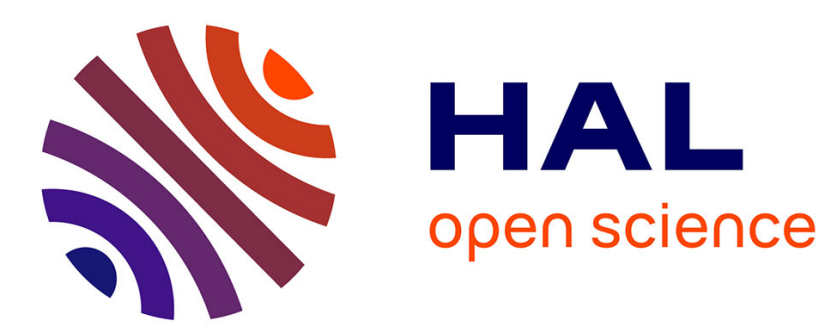

\title{
The Decomposition of a Process and the Definition of Interoperability Metrics
}

\author{
Mamadou Camara, Yves Ducq, Rémy Dupas
}

\section{To cite this version:}

Mamadou Camara, Yves Ducq, Rémy Dupas. The Decomposition of a Process and the Definition of Interoperability Metrics. INSIGHT - International Council on Systems Engineering (INCOSE), 2011, 14 (4), pp.15-16. hal-00661340

\section{HAL Id: hal-00661340 \\ https://hal.science/hal-00661340}

Submitted on 19 Jan 2012

HAL is a multi-disciplinary open access archive for the deposit and dissemination of scientific research documents, whether they are published or not. The documents may come from teaching and research institutions in France or abroad, or from public or private research centers.
L'archive ouverte pluridisciplinaire HAL, est destinée au dépôt et à la diffusion de documents scientifiques de niveau recherche, publiés ou non, émanant des établissements d'enseignement et de recherche français ou étrangers, des laboratoires publics ou privés. 


\section{The Decomposition of a Process and the Definition of Interoperability Metrics}

Mamadou Camara, mamadou.camara@ims-bordeaux.fr; Yves Ducq, yves.ducq@ims-bordeaux.fr; and Remy Dupas remy.dupas@ims-bordeaux.fr

Our research proposes an approach to graphically represent and measure the interoperability in an enterprise or a supply chain so that it can be improved. This approach is based on two simple principles. The first principle is that we must distinguish between business activities and non-value-added activities. The second principle is that process performance indicators can be used as interoperability measures.

We begin with the first principle, distinguishing between business activities and nonvalue-added (NVA) activities. Business activities create value in a business process. In ( IEEE 1990) interoperability is defined as the ability of two or more systems or components to exchange information and use the exchanged information without special effort from either system. The definition was chosen among many possible definitions because it suggests that the efforts of the systems to exchange information should be reduced and then eliminated to achieve interoperability.

To reduce and eliminate the efforts, however, one must be able to represent them first. Non-value-added activities are the parts of business processes that represent the efforts between partners to achieve the interoperability of information exchanges. Business process engineers proceed in two steps: in the first step they identify each activity as being either an NVA or business activity, and in a second step, they check in order to detect some activities that have been identified as business but are in fact subprocesses. It is necessary to break these activities up into both business and NVA categories.

Figure 1 represents a simple and linear business process made up of three activities. In the first step, the activities labeled A1 and A3 are identified as a full business activities and the activity labeled A2 is identified as a full NVA activity. In the second step, the activity labeled A3 is broken up in two parts labeled A31 (business activity) and A32 (NVA activity).

Next we come to the second principle, that process performance indicators (PIs) can be used as interoperability measures. Individual PIs are associated to each activity (business or NVA) generated by the identification and decomposition just described. For each business or NVA activity within the process, the following PIs can be calculated: average elapsed time, average cost, and percentage of failure (Yaxiong, Zhen, and Huibin 2010). The process PIs are average elapsed time, average cost, and percentage of failure at the process level. These are aggregations of the PIs for the NVA and business activities.

Ford, Colombi, Graham, and Jacques (2007) penalize the interoperability function when system pairs need translation, that can be considered as NVA, in order to interoperate. Our measurement of interoperability uses the same logic in that, given two versions of the same process, each model is penalized by the part of its performance that comes from the NVA activity it contains. As proposed by Chen, Vallespir, and Daclin (2008) and by Lebreton and Legner (2007), our measurement of interoperability is realized exclusively through the evaluation of cost, time, and quality (that is, percentage of failure). This choice relies on the assumption that these characteristics encompass all other types of interoperability efforts in the physical system. This means that several interoperability measures defined in the literature can be converted into process performance indicators.

If one can measure interoperability as this approach allows, then one can define a methodology that integrates several techniques and tools for analysis and evaluation, drawn from 
the business-process engineering or enterprise-engineering domains. For example, businessactivity monitoring and business-process simulation will be used to measure improvements in interoperability.

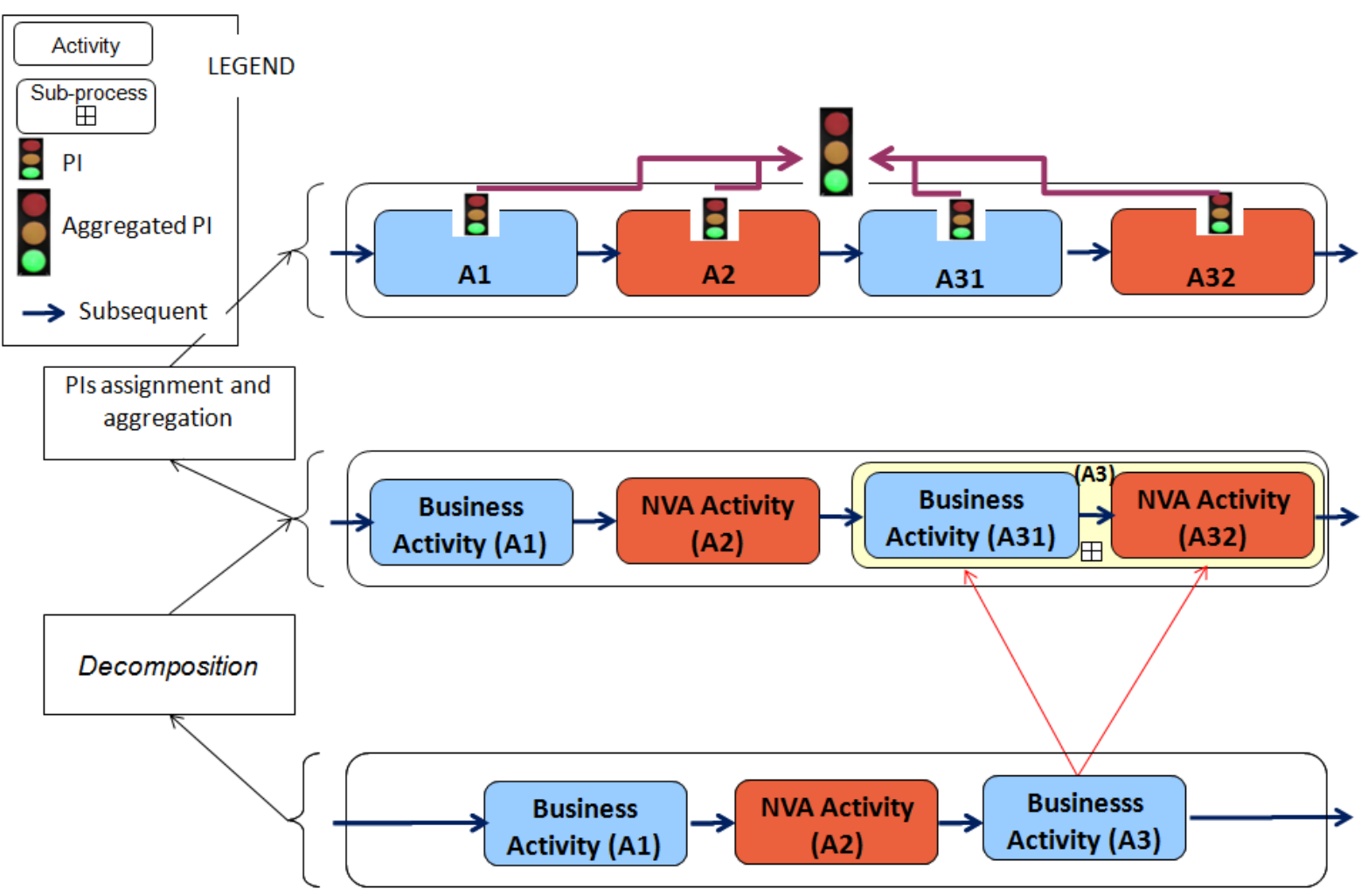

Figure 1. Representing and measuring interoperability

\section{References}

IEEE, 1990, "IEEE standard computer dictionary: a compilation of IEEE standard computer glossaries”, (1990)

Blanc, S. 2006. "Contribution à la caractérisation et à l'évaluation de l'interopérabilité pour les entreprises collaboratives.” PhD, University of Bordeaux 1, France.

Chen, D., B. Vallespir, and N. Daclin. 2008. “An Approach for Enterprise Interoperability Measurement.” Paper presented at the International Workshop on Model Driven Information Systems Engineering: Enterprise, User and System Models, Montpellier, France.

Ford, T., J. Colombi, S. Graham, and D. Jacques. 2007. “The Interoperability Score.” Paper presented at the Fifth Conference on Systems Engineering Research, Stevens Institute of Technology, Hoboken, NJ (US).

Lebreton, B., and C. Legner. 2007. "Interoperability Impact Assessment Model: An Overview.” In Enterprise Interoperability II: New Challenges and Approaches, ed. R. J. Goncalves, J. P. Müller, K. Mertins, and M. Zelm, pages 725-728. London: Springer.

Yaxiong, T., X. Zhen, and X. Huibin. 2010. "Bpm Exception Monitoring based on Process Knowledge.” Paper presented at the 2010 IEEE Conference on Cybernetics and Intelligent Systems - Singapore - June 28th-30 2010. 